\title{
Assessment of innovative market access options for banana value chain in Uganda
}

\author{
Ariho Alex ${ }^{1,2 *}$, Makindara Jeremia ${ }^{1}$, Tumwesigye George $^{3}$ and Sikira Anna ${ }^{1}$ \\ ${ }^{1}$ Sokoine University of Agriculture, Morogoro, Tanzania. \\ ${ }^{2}$ Forum for Agricultural Research in Africa (FARA), Accra, Ghana. \\ ${ }^{3}$ Great Lakes Regional University, Kanungu, Uganda.
}

Received 1 March, 2015; Accepted 9 September, 2015

\begin{abstract}
Smallholder banana farmers depend almost entirely on fresh banana for their livelihoods in Uganda. Similarly, other banana value chain (BVC) actors specialize in the trade of the fresh fruit for income and employment. Therefore, improving the efficiency of market access options in Uganda's banana subsector is one way that banana value chain actors can benefit through the sale of their banana products. In order to achieve this, the actors need to be innovative; departing from dependence on the same product and traditional markets/approaches that limit available benefits. This paper is aimed at identifying innovative market access options among the banana value chain actors in Uganda as a basis for projecting the potential. Cross-sectional research design incorporating $\mathbf{2 4 0}$ value chain actors was employed for the study. The major innovative market access options assessed during the study were collective marketing, contract farming, mobile phone platforms, value addition options and supermarkets. The study discovered that innovative market access options such as farmer associations/collective marketing groups, use of mobile phone tools and value addition among banana actors were vital in improving market access but were underutilized. As such, there is need to develop a specific banana value chain development strategic framework in order to tap up innovations among the value chain actors and promote their diffusion across key banana growing districts in Uganda.
\end{abstract}

Key words: Market access options, banana, value chain, innovation, Uganda.

\section{INTRODUCTION}

Bananas are a major staple food in Uganda constituting $70 \%$ of the family food basket (Bujoreanu, 2013). They are grown by approximately $75 \%$ of the country's farmers on $40 \%$ of the total arable land (PAEPARD, 2012). Additionally, Uganda is currently one of the world leaders in banana production, accounting for approximately $10 \%$ of total global production (FAOSTAT, 2006). The country produced $4,300,000$ tons in $2008,4,522,000$ tons in
$2009,4,694,000$ tons in 2010 and 4,895,000 tons in 2011 (UBOS, 2012). These statistics reveal that with such a vast amount of bananas produced, rural village markets in Uganda are highly unlikely to be meaningful avenues for market access since the majority of people in these localities are most likely to be banana producers (especially in major banana producing areas).

At present, the smallholder farmers in Uganda almost

*Corresponding author. E-mail: aariho@faraafrica.org.

Author(s) agree that this article remain permanently open access under the terms of the Creative Commons Attribution License 4.0 International License 
entirely depend on fresh banana produce for their livelihoods (Ssali, 2008). The practice has led to a negative impact on their wellbeing since the benefits derived from fresh banana are low (Sanyang, 2012). The situation necessitates the adoption of innovative market access options among banana producers and other value chain actors.

Market access options are alternative avenues through which a value chain actor(s) can supply and sell their product(s) to another value chain actor(s). Therefore innovative market access options are strategies involving change from the norm adopted by a value chain actor(s) to resolve a perceived constraint in the value chain especially when there is stiff competition in the traditional market channels. Innovative market access can therefore be achieved in three ways; (a) by identifying new market avenues (departing/improving the traditional markets or approaches e.g. fresh banana market, individual market access approach, farm gate and roadside selling) (b) by identifying and adopting an activity that the value chain needs in order to operate efficiently (it may be absent or in existence but underprovided) or (c) by creating a new or improving an existing product (reducing dependence on 'traditional' product e.g. fresh bananas). Adoption of innovative market access options facilitates efficiency in a value chain thereby improving the trade system and benefits along the value chain.

The banana value chain in Uganda has over a long time retained its traditional approach thus making it complex in nature; it has repetitive activities which could be handled by one or a few chain actors' e.g series of banana traders. However, in recent times due to increasing globalization through international trade, innovativeness has been embraced in order to reach the international consumers who want to retain their food culture. In the same way there has been an increase in banana funding (e.g. by Department for International Development, Forum for Agricultural Research in Africa and Uganda Government), changes in demographics (urbanization), transport and communication systems (modernization) as well as consumers' preferences which have necessitated the adoption of a theory of change in Uganda's banana sub-sector. As noted by Bouris et al. (2011) farmers' access to markets is majorly influenced by their product's ability to meet the consumers' criteria. The high competition in agricultural markets is primarily due to the oversupply of certain products as a result making it increasingly vital for value chain actors to engage in innovative marketing practices in order to link their products with the market place. Therefore, this study is aimed at assessing innovative market access options and actors as a basis for showing the increased need for change in the banana sub-sector for increased benefits among the value chain actors.

The research questions that guided this paper were; 'Who are the key drivers/actors in banana value chain in Uganda?' 'What roles do the actors play in the value chain development?' 'What innovative marketing options exist in Uganda for banana products and services?' and 'Factoring in innovativeness, what is the ideal banana value chain in Uganda?'.

\section{THEORETICAL APPROACH}

This study adopted diffusion of innovation theory in order to identify the innovative market access options and actors in the banana value chain. Innovation refers to an idea, practice or project that is perceived as new by an individual or other unit(s) of adoption (Sahin and Thompson, 2006). From literature, innovations have the following qualities: relative change, compatibility, complexity, trialability and observability (Rogers, 1995). Relative change is the degree to which an innovation is perceived as better than the idea it supersedes. Innovative market access options are considered to be more beneficial compared to traditional approaches. Compatibility is the degree to which an innovation is perceived to be consistent with the existing values, past experiences and needs of potential adopters while complexity is the level of simplicity or difficulty involved in the adoption of a given innovation. The endorsement of innovative market access options among banana value chain actors is pegged on the improvement of the existing products and markets which are considered easy to adopt. Trialability is the degree to which an innovation may be experimented with on a limited basis while observability is the degree to which the results of an innovation are visible to others; the easier it is for individuals to see the results of an innovation the more likely it is that it will be adopted. Considering that innovative market access options have been adopted by some actors this translates to ease of implementation due to observability.

Innovativeness is closely linked to or rather is an ingredient of entrepreneurship and is affected by attitude and perception. Amorós and Bosma (2013) observe that fear of failure and availability of (good) job alternatives in an economy further contributes negatively to entrepreneurship of individuals. That is why creation of awareness and promotion of entrepreneurship should be on top of policy agendas in economies in Uganda and specifically for bvc development. As was evident from the Global Entrepreneurship Monitor (GEM) report, Uganda ranks highly in entrepreneurial intentions at $60.7 \%$ compared to other countries in Sub Saharan Africa such as South Africa at $12.8 \%$, Nigeria at $46.8 \%$ and Zambia at $44.5 \%$, Latin America and Caribbean (average $32.5 \%$ ), Middle East and North Africa (average 38.2\%), Asia Pacific and South Asia (average 20.9\%), Europe-EU28 (average 13.5\%), Europe-Non-EU28 (average 13.7\%) and North America (average 12.9\%). This shows high willingness of the Ugandan people to be entrepreneurs. However, the report further shows low new business 
initiation and ownership at $20 \%$ in Uganda although above Africa's average of $15.5 \%$; an indicator of low implementation and perhaps low level of enablers in realizing individual intentions. Therefore, there is need to identify innovativeness in order to set strategic enablers in agricultural value chains as well as build on the existing structures and systems to create a new system of agriculture transformation that addresses existing barriers and unaffordable policies to support high level entrepreneurial spirit among actors.

\section{METHODOLOGY}

\section{Study area}

This paper draws information from a study carried out in Mbale district located in Eastern Uganda, and Kabale and Mbarara districts in South Western region. The areas were selected based on their differences in banana production and market characteristics. Mbarara district is characterized by high banana production whereas Kabale and Mbale are characterized by medium and low production levels respectively. Mbale and Kabale districts share a border with Kenya and Rwanda respectively and thus experience cross border effects, different market arrangements from the rest of Uganda.

\section{Research design}

The paper used a cross-sectional research design, employing both quantitative and qualitative research methods (mixed methods) as championed by McCormick and Schmitz (2001 in collecting data from the main banana value chain actors. In order to increase the reliability and precision of data, a triangulation method (interviews, focus group discussion and literature review) was adopted as endorsed by Creswell (2009) and Grajek and Kretschmer (2009). Semi structured questionnaires, key informant interviews and focus group discussions were used as tools for data collection.

\section{Sampling design}

The paper employed a multi stage sampling technique where in the first stage three districts (Kabale, Mbale and Mbarara) were purposively selected since they had varying characteristics in terms of production, marketing and value chain development so as to ensure representativeness of the sample for Uganda. In the second stage, two sub-counties and two parishes from each sub-county, that is, four parishes per district were purposively selected while in the third stage a total of 240 actors whereby twenty value chain actors were selected per parish using simple random sampling technique.

\section{Data analysis}

To determine innovative market access options and actors in the banana value chain, data was analysed through descriptive techniques; means, percentages and frequencies using Microsoft Excel, STATA and Statistical Packages for Social Sciences (SPSS). In addition, ranking of opportunities was done as per key informants views.

\section{RESULTS AND DISCUSSION}

\section{Major banana value chain actors and roles played in Uganda}

The major banana value chain actors identified during the study included farmers/producers, loaders, transporters, traders (micro-traders, bulk traders and retailers), crafts makers, processors facilitators (state and non-state actors) and consumers (Table 1). The major role each plays is an indicator of their importance in the current BVC and its development.

Banana producers are the main players in the BVC, who are mainly smallholder farmers with farm size ranging between 0.5 to 4 acres. The producers rarely use external inputs such as inorganic fertilizers, tissue culture seedlings and chemicals (at less than 1\%) whereas approximately $18 \%$ use farm yard manure. Their main sources of seedling (sucker) are from older plantations or neighbours. The producer market approach is through sale of a few bunches of banana to bicycle traders at a go, at the farm gate and or village centres.

Micro traders whose main mode of transport is bicycles move from one farm to the other in search of banana to purchase, either through random checks or referral. They are preferred by banana producers since they ease the transport burden to village markets. These traders mainly fill in the collective function for nonexistent or non functional farmers' marketing groups.

Market vendors operate on a higher scale than bicycle traders. Their major market points are village markets where they buy from farmers and bicycle traders then move the bananas to bigger market points where bulk traders collect them. They mainly have an established relationship with bulk traders which ease their functionality.

Loaders and transporters in the BVC have an important role in moving banana to urban markets. However, they also supply banana to institutions such as schools and hotels. Loaders have the role of carrying and packing banana in green banana leaves, sacks and or in vehicles whereas transporters move bananas on behalf of bulk traders to their preferred market. Transporters act as a key link between rural banana production points to urban consumers.

Retailers are located in village and urban markets, where they sell banana products to small consumers mainly purchase a few fingers or cluster at a time. They also operate in residential neighbourhoods to ease consumer's banana market accessibility.

Some banana bulk traders also function as exporters whose main role is to move banana to international markets mainly to Kenya, Rwanda and United States of America. Exporters are mainly keen on quality in order to meet banana consumer attributes. Banana processors 
Table 1. Major banana value chain actors and roles played in Uganda.

\begin{tabular}{|c|c|c|}
\hline $\begin{array}{l}\text { Value chain } \\
\text { actors }\end{array}$ & Major role(s) & Characteristics \\
\hline Producers & $\begin{array}{l}\text { Undertake banana production activities; Engage in } \\
\text { farm gate and trading points (village level) selling; } \\
\text { Human or bicycle transport to markets; Consume a } \\
\text { significant portion of their banana produce }\end{array}$ & $\begin{array}{l}\text { Are mainly smallholders (0.5-4acres); Use basic farm } \\
\text { implements and traditional techniques in plantation } \\
\text { management; Use suckers from own/neighbours } \\
\text { farms as a means of plantation maintenance or } \\
\text { expansion; Mainly sell produce to micro/bicycle } \\
\text { traders }\end{array}$ \\
\hline $\begin{array}{l}\text { Micro/bicycle } \\
\text { traders }\end{array}$ & $\begin{array}{l}\text { Involved in collection of bananas from farms to } \\
\text { collection points;Act as a link between farmers and } \\
\text { markets }\end{array}$ & $\begin{array}{l}\text { They operate on a very small scale (transport and } \\
\text { trade 1-5 banana bunches at a time) }\end{array}$ \\
\hline $\begin{array}{l}\text { Market } \\
\text { vendors }\end{array}$ & $\begin{array}{l}\text { Undertake collection of bananas from bicycle traders; } \\
\text { Acts as agents for lorry traders (bulk traders) }\end{array}$ & $\begin{array}{l}\text { Operate on considerable higher scale than micro- } \\
\text { traders but less than bulk traders; Have an } \\
\text { established relationship with bulk traders }\end{array}$ \\
\hline Loaders & Involved in loading of bananas into banana carriers & Are casually engaged by bulk traders \\
\hline Transporters & Offer transport services to bulk traders & Operate in large scale (large investment) \\
\hline $\begin{array}{l}\text { Bulk } \\
\text { traders }\end{array}$ & $\begin{array}{l}\text { Undertake bulking of bananas from major rural trading } \\
\text { points; Involved in long distance transport of bananas } \\
\text { from rural areas to major urban centres }\end{array}$ & $\begin{array}{l}\text { Operate in large scale level (large investments); Act } \\
\text { as a link between urban consumers and rural banana } \\
\text { sources }\end{array}$ \\
\hline Retailers & $\begin{array}{l}\text { Buy from large/bulk traders and sell to consumers; } \\
\text { Supply bananas to consumers in quantities they } \\
\text { want/they can afford }\end{array}$ & $\begin{array}{l}\text { Operate on small scale; Are involved in selling other } \\
\text { goods other than bananas; Operate in major markets } \\
\text { to next door kiosks in residential areas }\end{array}$ \\
\hline Exporters & $\begin{array}{l}\text { Involved in large scale production or buy from } \\
\text { producers directly; Regional exporters buy bananas } \\
\text { from bulk traders or bulk themselves; Distribute } \\
\text { banana products to the international markets }\end{array}$ & $\begin{array}{l}\text { Operate in large scale (involve large volumes); Are } \\
\text { keen on quality; Have specific long-term relationships } \\
\text { (network) with traders in other countries }\end{array}$ \\
\hline Processors & $\begin{array}{l}\text { Undertake transformation of fresh bananas/banana } \\
\text { plant parts; Involved in consumer awareness creation } \\
\text { on processed banana products }\end{array}$ & $\begin{array}{l}\text { Operate on a small scale due to consumer } \\
\text { unawareness }\end{array}$ \\
\hline $\begin{array}{l}\text { Value chain } \\
\text { facilitators }\end{array}$ & $\begin{array}{l}\text { Provision of advisory services; Value chain } \\
\text { development ; } \\
\text { Funding of value chain activities }\end{array}$ & $\begin{array}{l}\text { Mostly incorporate banana promotion in their } \\
\text { activities along with other theme areas; Undertakes } \\
\text { research and development initiatives }\end{array}$ \\
\hline Consumers & Provide market for banana products & $\begin{array}{l}\text { Ranges from small (individuals and households) to } \\
\text { big (restaurants and institutions) consumers }\end{array}$ \\
\hline
\end{tabular}

mainly operate on a small scale in transforming banana fruit and banana tree parts to other products in order to boost their market access ability.

Value chain facilitators provide services to BVC actors, that is, provision of advisory services such as extension, finance and research. In the current banana value chain in Uganda, the value chain facilitators are weakly linked to BVC actors thereby constraining the value chain operation. The main banana consumers in Uganda are households, although hotels and institutions (such as schools) are also major consumers.

\section{Innovative market access options and actors in Uganda}

Results of the study indicated that although $18 \%$ of the farmers were members of farmer groups, only $3 \%$ of the banana farmers sold their bananas as a group, that is, the majority (97\%) sold their banana produce individually (Table 2). These findings indicate inactivity of the existing farmer groups as indicated during the farmer group discussions despite of the recent high investment in formation of groups under NAADs by Ministry of Agriculture. This could be further attributed to low trust among farmers even when in a group, thus making them unable to sell their banana produce collectively. The findings are an indicator of the opportunity for private sector investment in addressing the actors' constraints along the BVC. The results were similar to the findings of Ngambeki et al. (2010) in the study of banana market distortions in Uganda who found that an estimated of $19 \%$ of banana farmers sold their banana produce through farmer groups and contracting. The relationship between 
Table 2. Farmers' descriptive characteristics for innovation and value addition.

\begin{tabular}{|c|c|c|c|c|c|}
\hline Farmers & Category & Mbale (\%) & Kabale (\%) & Mbarara (\%) & Overall (\%) \\
\hline \multirow{5}{*}{$\begin{array}{l}\text { Banana value chain } \\
\text { innovation }\end{array}$} & Packing in sacks & 10 & 0 & 0 & 3 \\
\hline & Chips & 2 & 0 & 2 & 2 \\
\hline & Crafts & 20 & 0 & 0 & 6 \\
\hline & Marketing innovation & 3 & 0 & 7 & 3 \\
\hline & Fertilizer use (manure) & 18 & 0 & 35 & 18 \\
\hline \multirow{2}{*}{$\begin{array}{l}\text { Access to value addition } \\
\text { information }\end{array}$} & Have access & 40 & 41 & 49 & 44 \\
\hline & Do not have access & 60 & 59 & 51 & 56 \\
\hline \multirow{2}{*}{$\begin{array}{l}\text { Banana value addition } \\
\text { knowledge }\end{array}$} & Have knowledge & 72 & 46 & 70 & 65 \\
\hline & No knowledge & 28 & 54 & 30 & 35 \\
\hline \multirow{2}{*}{ Value addition } & Do value addition & 37 & 20 & 14 & 23 \\
\hline & Do not & 63 & 80 & 86 & 77 \\
\hline \multirow{2}{*}{$\begin{array}{l}\text { Gender proportion in value } \\
\text { addition }\end{array}$} & Male & 33 & 88 & 83 & 59 \\
\hline & Female & 67 & 12 & 17 & 41 \\
\hline \multirow{8}{*}{ Banana value addition } & Ripening & 3 & 0 & 5 & 2 \\
\hline & Roasting & 5 & 0 & 0 & 2 \\
\hline & Pancakes & 3 & 0 & 0 & 1 \\
\hline & Crisps & 3 & 0 & 0 & 1 \\
\hline & Juice & 3 & 2 & 2 & 2 \\
\hline & Wine/local brew & 8 & 20 & 9 & 12 \\
\hline & Drying & 5 & 0 & 2 & 2 \\
\hline & Craft & 20 & 0 & 0 & 6 \\
\hline \multirow{2}{*}{ Mobile phone ownership } & Those who own & 63 & 46 & 72 & 60 \\
\hline & Those who do not own & 37 & 54 & 28 & 40 \\
\hline \multirow{8}{*}{ Market information channels } & Mobile phone & 33 & 15 & 28 & 25 \\
\hline & Internet & 3 & 2 & 0 & 2 \\
\hline & Market boards & 15 & 5 & 14 & 11 \\
\hline & Media & 3 & 0 & 23 & 9 \\
\hline & Market visit & 33 & 15 & 12 & 19 \\
\hline & Cooperative group & 0 & 0 & 2 & 1 \\
\hline & Other bvc actors & 25 & 37 & 33 & 31 \\
\hline & Neighbors and relatives & 50 & 41 & 19 & 36 \\
\hline
\end{tabular}

group membership and the proportion of farmers who sell through these groups was an indicator of the reverse gains in collective banana marketing.

This study observed that contract farming was increasingly being favoured by exporters and processors as a basis for acquiring quality bananas. Exporters such as Afri Banana Products LTD had established a fresh banana contract with the locals in Mbarara towards its Fresh Vacuum Sealed Matoke (FREVASEMA) export to the United States of America. Banana wine and juice makers had established non-formal contracts with farmers and traders in provision of banana as the need arose. This was discovered to be an avenue for increased returns by the participants, which implied that contract farming was among the pronounced options for market access.

The results of the study also pointed out that mobile phones as a platform of information communication technology presented a viable avenue for bridging the existing gap in acquiring timely market information as evidenced by $25 \%$ of the farmers compared to $16 \%$ of traders. However, mobile phones are underutilized in market information access where only $25 \%$ indicated having used mobile phone tools in accessing market information compared to $60 \%$ mobile phone ownership among banana farmers (Table 2). The ownership is quite substantial although farmers do not exploit the information and communication technology (ICT) potential 
for better market access. However, the study established high potential growth in market access and technology transfer through technology transfer among BVC actors. Guidi (2011) indicated that deficits in rural infrastructure among which is the communication infrastructure hinder agricultural transformation. The underuse of mobile phone gadgets among banana farmers overlooks access to crucial market information which would otherwise be a game changer in the banana market. As noted by USAID (2011) provision of market price information helps actors in agricultural value chains in promoting efficient production and trade. Such information enables producers to; negotiate for better terms with traders, decide whether or not to harvest at a later date, store their produce, choose what markets to sell to and even influence their plans on future crop choices. In a study on the impact of mobile phone coverage Uganda, Muto (2008) affirmed that the provision of market information influences participation in horticultural markets. This is explained by the need for timely sale of horticultural products since they are highly perishable. Therefore, mobile phones present an innovative market access platform which may facilitate efficient trade systems in the banana value chain given that bananas are also significantly perishable hence increased returns to investment.

Results from the study further indicated a limitation of market information as evidenced by banana farmers' dependence on neighbors' and relatives (36\%) as their preferred source of market information; a social network platform (Table 2). On the other hand, traders' main source of information was other value chain actors as evidenced by $57 \%$ of the respondents. This observation presents a high risk for value chain actors in making informed decisions relating to price determination, what market to sell to and when to sell their banana produce. The parties in a social network platform were characterized by either withholding crucial information or misrepresenting it i.e. information asymmetry, thus constraining market access as well as benefits derivable from banana trade. The findings were similar to those of Ngambeki et al. (2010) who established that the major information source in the banana value chain were the traders and middlemen followed by other farmers. The potential bias of sources increases the likelihood of misinformation especially from traders and middlemen who could provide information geared to favor them.

The study found that brewing was the most common form of value addition among the value chain actors, being practiced by $12 \%$ of the farmers. Although the results indicated $44 \%$ of the respondents had access to value addition information and approximately $65 \%$ indicated they were aware of banana value addition, only $23 \%$ were involved in value addition (Table 2 ). The study revealed that $27 \%$ of banana was set aside for value addition by farmers. Banana beer and wine presented a cheaper and nutritious option of alcoholic drinks thus being preferred by rural dwellers and as a result promoting the local economy.

Supermarkets are increasingly being used for value added banana products (wine, juice, crisps, cakes) as an innovative platform for reaching the middle and high income markets. This presents an opportunity for investment in banana value addition for employment creation and income generation through commercialization of existing cottage industries.

Banana traders were found to be innovative by packing banana in sacks as a way of retaining banana quality during transportation, brewing and trading waragi and tonto as well as cooking and selling banana chips. The study ascertained that $27 \%$ of the fresh banana purchased by traders for sale is set aside for value addition that is, ripening, roasting, juicing, crisps making and brewing. He traders main mode of market information access was through other value chain actors $(57 \%)$ followed by market visit at $27 \%$, mobile phones at $16 \%$ and neighbours and relatives at $14 \%$ respectively (Table 3).

Product exchange and craftsmanship designs were established as upcoming avenues in the development of the banana value chain. Environmental friendly charcoal makers (especially in urban areas) used banana waste products such as banana peels and stems in making charcoal briquettes. The households and or individuals who supplied banana waste were given charcoal briquettes in exchange thus resolving the waste menace and fuel demand concurrently. The packaged charcoal briquettes have penetrated the supermarket segment as clean energy alternatives for urban dwellers. Craftsmanship designs using banana 'waste' products such as banana stems have also been increasingly developed as an alternative avenue for gaining access to the market thus departing from dependence on fresh banana produce. The fibre from the banana waste is used by craftsmen in designing lamp stands, hats, ornaments, baskets and paper bags which are biodegradable. This innovativeness is increasingly gaining favour in the market and can thus be utilised as a tool for banana value chain development. The results are an indicator of the great potential in banana waste management in Uganda as a source of job and wealth creation.

From the study collective marketing followed by contract farming and value addition were considered as the most preferred market access strategies. On the other hand, craftsmanship designs and product exchange were ranked as the lowest promising market access options. However the last two options were cited as highly innovative and likely to catch up with the rest of market access options due to increasing environmental promotion debates related to climate change across the world. Collective marketing was ranked as the best innovative market access option due to reduced transaction 
Table 3. Traders' innovation, value addition and marketing.

\begin{tabular}{|c|c|c|c|c|c|}
\hline Variable & Category & Mbale (\%) & Kabale (\%) & Mbarara (\%) & Overall (\%) \\
\hline \multirow{3}{*}{$\begin{array}{l}\text { Banana value chain } \\
\text { innovation }\end{array}$} & Packing in sacks & 20 & 5 & 13 & 11 \\
\hline & Chips & 13 & 5 & 0 & 7 \\
\hline & Banana brew trade & 7 & 57 & 0 & 27 \\
\hline \multirow{5}{*}{$\begin{array}{ll}\text { Value } & \text { addition } \\
\text { participation } & \end{array}$} & Ripening & 7 & 10 & 13 & 9 \\
\hline & Roasting & 7 & 0 & 13 & 5 \\
\hline & Banana crisps & 0 & 5 & 0 & 2 \\
\hline & Banana juice & 0 & 0 & 25 & 5 \\
\hline & Banana wine & 7 & 48 & 0 & 25 \\
\hline Banana value added & Proportion & 26 & 37 & 20 & 27 \\
\hline \multirow{6}{*}{ Information channels } & Mobile phone & 13 & 10 & 38 & 16 \\
\hline & Internet & 0 & 5 & 0 & 2 \\
\hline & Media & 7 & 5 & 13 & 7 \\
\hline & Market visit & 40 & 24 & 13 & 27 \\
\hline & Other banana value chain actors & 60 & 57 & 50 & 57 \\
\hline & Neighbours/relatives & 0 & 24 & 13 & 14 \\
\hline
\end{tabular}

Table 4. Differences between traditional and innovative market access options.

\begin{tabular}{ll}
\hline Traditional market access options & Innovative market access options \\
\hline Many actors and small production units & Very few actors and large production units \\
Lack of standards to adhere to in production & Standards and certification to adhere to in production and processing \\
No direct information access options on product and & Direct market and product information access via information \\
processing & communication technology \\
Little/no processing and value addition & Advanced processing and value addition \\
Market based governance structures & Quasi hierarchical governance \\
Trader driven & Buyer/consumer driven \\
\hline
\end{tabular}

costs, high returns from better prices and ability to bypass middlemen within the BVC. The study identified contract farming as the second most preferred market access option basically due to assured market by farmers across Mbale, Mbarara and Kabale. The paper recognised innovative market access options such as mobile phones and was associated with timeliness and cost effectiveness by farmers and traders. Value addition was also ranked highly (third) as a promising market access option with benefits associated to extended shelf life, access to high end markets and provision of product varieties to consumers. The study across the three study districts established other innovative market access options such as social networks, supermarkets, product exchange and craftsmanship among other options embraced by BVC actors.

From the study it was clear that a range of banana value chain actors were innovative given various engagements and options explored to meet market demand. However, processors and exporters were considered as the most innovative (as ranked by key informants) considering their market approach of supplying the fresh bananas in distant markets. The ability to extend the shelf life of fresh bananas serves as a basis for scaling up to international trade with other banana demanding markets. Similarly the product exchange and craftsmanship designs market access options were considered highly innovative whose diffusion has been slow. In addition, as noted in the study there is increasing number of innovative actors who are focused on developing consumer tailored banana products meant to meet existing demand and resolve challenges in the BVC. Consequently, the trend will improve the banana trade system though little by little. Critically, the diffusion of innovations like the extension of banana shelf life and processing are constrained by the intellectual property rights.

The findings of the study established major differences between traditional and innovative market access options (Table 4). Key among these was the buyer/consumer 


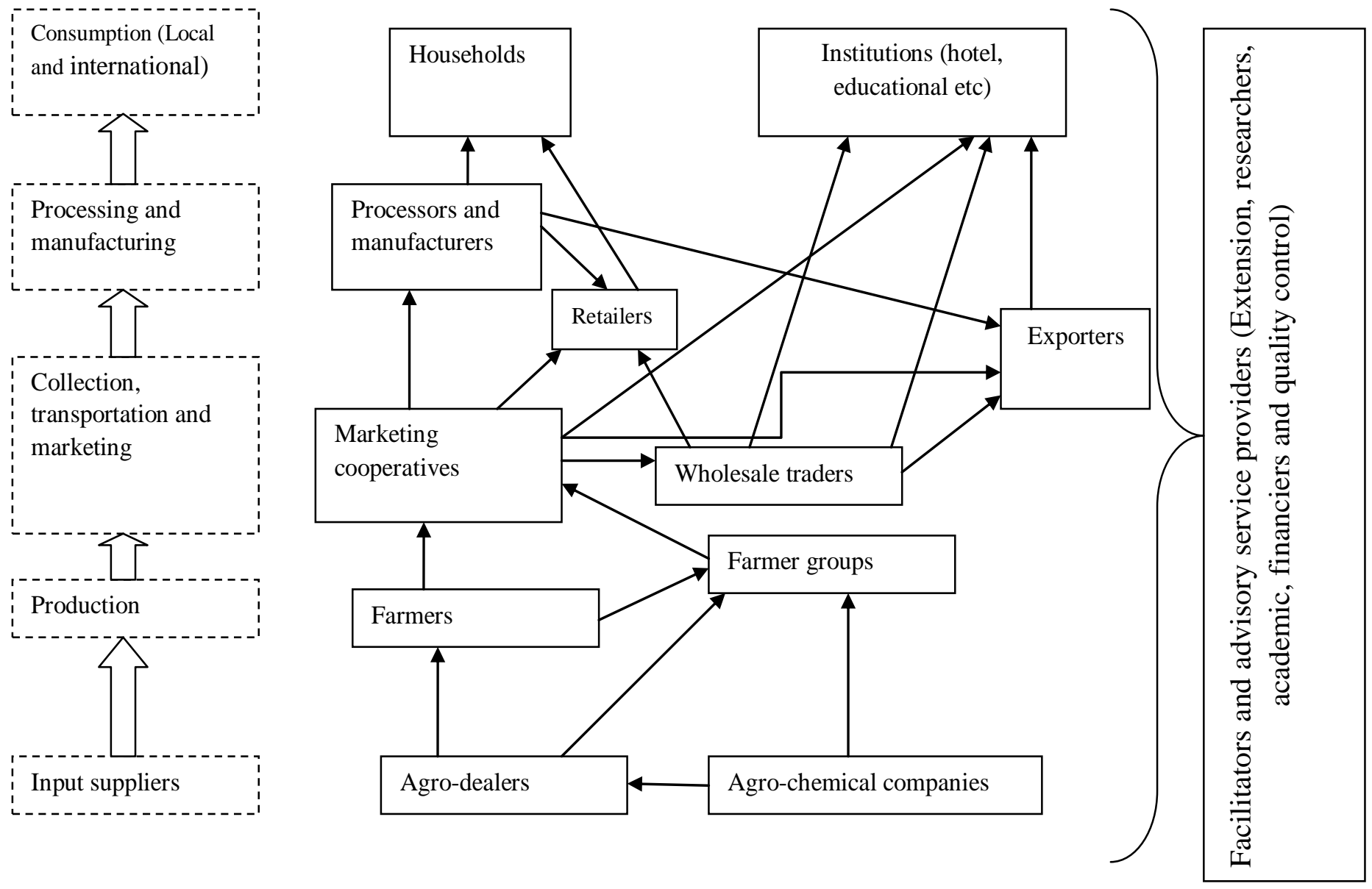

Figure 1. The ideal banana value chain in Uganda.

drive in innovative market access options compared to traditional trade drive. Therefore in today's market structures innovative market access options are superior compared to the traditional market access options as had been ascertained by Keane (2008).

\section{Innovativeness and banana value chain}

Through the adoption of innovative market access options (diffusion), the long and complex banana value chain in Uganda could highly be transformed. These options include the bypassing of micro traders and market vendors and transferring those roles to structured farmer organizations. As a result the time taken in distributing banana products to consumers would be notably reduced hence improving the quality of bananas (freshness) offered in the market. Further, the linking of producers to input dealers as well as bridging the gap between financial facilitators to value chain actors would be a potential basis for improving the efficiency in the banana value chain as well as innovativeness. Through these innovations, trade efficiency in the banana value chain would be improved. This study narrowed down to the value chain below as an ideal banana value chain for Uganda (Figure 1).

\section{CONCLUSIONS AND RECOMMENDATIONS}

From the study it was evident that the producers, loaders, transporters, traders (micro-traders, bulk traders and retailers), craftsmen, processors, facilitators (state and non-state actors) and consumers were the major actors in the banana value chain in Uganda. The micro-traders were the main link between the producers and the market. Although micro-traders are considered as middlemen by producers, they perform an important function that could be run by producer organizations in an ideal trade system and thereby contribute to BVC efficiency. Input dealers and financial facilitators had a notably weak and in many instance an absent link to banana producers which impacts negatively on the BVC trade efficiency. These actors would have played a major role as production and market enablers respectively. In this case, National Agricultural Advisory Services (NAADS) 
could play a vital role. There was a noted increase in innovativeness among the banana value chain actors with processors and exporters leading the adoption of innovative market access options through the extension of fresh banana shelf life. Product exchange and craftsmanship were observed as being the most promising avenues in market access. The diffusion of innovations was found to be instrumental in the development of the banana value chain; however, intellectual property rights in the case of processors and exporters were identified as constraint. Financiers and government could play a crucial role in catalysing the diffusion of innovations by availing necessary facilitation to the value chain actors. As a basis of easing market access, the study recommends the need for documentation of innovation efforts in all districts across Uganda and capacity building of the innovative actors in order to raise awareness and in turn promote innovations diffusion which will contribute to the BVC development. The study sought to explore innovation efforts in the banana value chain, however further assessment in innovation and incubation being advocated by funding organizations is required in order to understand their feasibility and contribution to value chain sustainability.

\section{Conflict of Interest}

The authors have no conflict of interest whatsoever.

\section{ACKNOWLEDGEMENTS}

Appreciation is extended to co-authors of this paper for providing helpful input and contributions to make this paper publishable. The authors are grateful to acknowledge the assistance of Karani Charles, Tusigwire Sarah, Muhumuza Osbert and Byarugaba Chris for their support during data collection for this study. Special thanks to Prof. Jonny Mugisha for his support in reading this paper and his advice.

\section{REFERENCES}

Amorós J, Bosma N (2013). Global entrepreneurship monitor 2013 global report: Fifteen years of assessing entrepreneurship across the globe. Global Entrepreneur Research Association (GERA).

Bouris J, Kaldis P, Alexopoulos G, Giannouzakou A (2011). Agricultural Marketing Competitive Strategies and Innovative Practices in Greece. International Scientific Conference eRA-6 19-24 September TEI Piraeus.

Bujoreanu L (2013). The Power of Mobile: Saving Uganda's Banana Crop. Accessed on October $3^{\text {rd }} 2013$ from http://blogs.worldbank.org/ic4d/the-power-of-mobile-saving-ugandasbanana-crop.
Creswell J (2009). Research design: Qualitative, quantitative, and mixed methods approaches. Thousand Oaks, CA: SAGE Publications.

FAOSTAT (2006). Statistics data base. Accessed $2^{\text {nd }}$ February 2013 from http://faostat.fao.org.

Grajek M, Kretschmer T (2009). Usage and diffusion of cellular telephony, 1998-2004. Int. J. Ind. Organ. 27(2):238-249.

Guidi D (2011). "Sustainable Agriculture Enterprise: Framing Strategies to Support Smallholder Inclusive Value Chains for Rural Poverty Alleviation." CID Research Fellow and Graduate Student Working Paper No. 53. Center for International Development at Harvard University.

Keane J (2008). A 'new' approach to global value chain analysis. Working paper 293. Overseas development institute: London.

McCormick D, Schmitz H (2001). Manual for value chain research on home workers in the garment industry. Accessed on $20^{\text {th }}$ September 2013 http://www.ids.ac.uk/ids/global/pdfs/WiegoManualendNov01.pdf

Muto M (2008). Impacts of mobile phone coverage expansion on market participation: panel data evidence from Uganda. Japan Bank for International Cooperation.

Ngambeki D, Nowakunda K, Tushemereirwe W (2010). The Extent and Causes of Banana (Musa spp.) Market Distortions in Uganda. Kampala, Uganda.

PAEPARD (2012). Matooke Agribusiness Incubator. Retrieved from http://paepard.blogspot.com/2012/10/matooke-agribusinessincubator.html

Rogers E (1995). Diffusion of Innovations (Fourth Edition). The Free Press, New York.

Sahin I, Thompson A (2006). Using Rogers' Theory to Interpret Instructional Computer Use by COE Faculty. J. Res. Technol. Educ. 39(1):81-104

Sanyang $S$ (2012). Uganda: Bananas are on demand but farmers are not taking advantage. FARA. Forum for Agricultural Research in Africa. Accessed on $10^{\text {th }}$ April 2013 http://allafrica.com/stories/200810290319.html

Ssali MJ (2008). Bananas are on Demand. Kampala, Uganda.

UBOS (2012). 2012 Statistical Abstract. Republic of Uganda.

USAID (2011). Using ICT to Provide Agriculture Market Price Information in Africa. Briefing paper, USAID. 